\title{
The 1925 Geneva Protocol: China's CBW Charges Against Japan at the Tokyo War Crimes Tribunal
}

\author{
Jeanne Guillemin
}

\begin{abstract}
The 1925 Geneva Protocol, which bans the wartime use of chemical and also biological weapons, was an emphatic reaction to the use of chemical weapons in World War I, but legal institutions that would sanction violations of the treaty have evolved only with difficulty. An important example of a legal failure to support the protocol occurred at the 1946-1948 International Military Tribunal for the Far East (IMTFE), just when it might be expected that Imperial Japan would be charged for its chemical and biological warfare (CBW) waged against China from the late 1930s into World War II. In 1937, the Chinese officially presented its first complaints to the League of Nations about Japan's battlefield use of chemical weapons (mustard gas, phosgene and tear gases) against defenseless Chinese troops and civilians. In addition, in early 1941 and after, China accused Japan of launching plague attacks against key Chinese cities, killing hundreds and terrorizing thousands. None of these accusations, although supported by evidence, brought about serious international recriminations for Japan. Once World War II ended, China expected to revive these charges at the IMTFE in Tokyo. Instead, under the influence of a few key figures in US military intelligence, the trial's International Prosecution Section (IPS) deleted the Chinese charges and for decades Japan's infraction were lost to history. Analysis of this legal failure points to the obstacles posed by growing Cold War antagonisms between the United States and the Soviet Union, which prompted a general American retreat from prosecuting Japan, its new democratic ally in East Asia, as well as the internal processes at the IPS that favored more blatant incidents of Japanese wartime aggression-such as the well-documented 1937 "Rape of Nanjing" and abuses of Allied prisoners of war. After the silence imposed at the IMTFE, chemical and biological weapons proliferated with few restraints until the Cold War ended in 1992. At the same time, the international framework for war crimes prosecution greatly changed with greater attention put on crimes against civilians. Yet, lacking precedent, international readiness to legally sanction violations of the Geneva Protocol-as with the
\end{abstract}

\footnotetext{
J. Guillemin $(\bowtie)$

Security Studies Program, MIT Center for International Studies Cambridge,

Cambridge, MA, USA

e-mail: jeg@mit.edu

(C) The Author(s) 2017

B. Friedrich et al. (eds.), One Hundred Years of Chemical Warfare: Research,

Deployment, Consequences, DOI 10.1007/978-3-319-51664-6_15
} 
2013 and 2017 murders of Syrian civilians with nerve gas-remains nearly as ambiguous as it was in 1946.

\section{Introduction}

Much of the history of war in the nineteenth and twentieth centuries was shaped by the great tension between advanced mechanized warfare and the idealistic ventures that arose to stop its mounting catastrophic impact. The nineteenth-century rise of national armies and industrial advances in weaponry began a pattern of increasingly destructive conflicts - the mass slaughter of troops and ruination of terrain - followed by valiant attempts to restrict the conduct of war, which were then followed by worse wars with more dangerously powerful and efficient weapons. The battlefield carnage and economic disruption caused by the Crimean War (1853-1856) and the American Civil War (1861-1865) were deplored. Yet in their aftermath, major state militaries plunged ahead to acquire more efficiently designed rifles, mobile heavy artillery, and machine guns.

The 1899 and 1907 Hague Conventions were a breakthrough in articulating new norms to reinforce the concept that the "right of belligerents to adopt means of injuring the enemy is not unlimited" (Boserup 1973, 152). Along with promoting the rights of prisoners of war and the protection of hospital ships, the conventions addressed specific weapons. The use of armed balloons on civilian populations and of expanding "Dum Dum" bullets (named after the British factory in India that produced them) were prohibited. The use of "smoke and noxious gas" in war was also prohibited, no small matter at the time (Hudson 1931). The role of chemicals in the production of weapons was well established and accelerating, with a growing impact on battlefield combat (Smart 2004). Gunpowder produced sickening sulfur fumes; sulfuric acid was used to make nitric acid, which was then used to make mercury fulminate for percussion caps, which meant more toxic clouds from explosives. New ideas to make weapons of chloroform, hydrochloric acid, cyanide, arsenic, and nauseating smokes and stink bombs in war started circulating in the 1860s. Other toxic substances poised for military use were chlorine, hydrogen cyanide, cyanogen chloride, phosgene, and mustard agent, all discovered or synthesized in the late eighteenth and early nineteenth centuries (Sartori 1943).

The 1907 Hague Conventions extended the 1899 provisions beyond their original five-year limit. The major Western powers appeared committed to the conventions, as did Japan and China. In 1915, though, Europe blundered into World War I and a new epoch of weapons innovations began. This time, long-range mortar, tanks, submarines with torpedoes, and the introduction of fighter airplanes expanded the dimensions of battle.

A major innovation in World War I was the introduction of chemical weapons, invented to overcome the conventional boundaries of trench warfare. In April 1915 at Ypres in Belgium, the German military released 150 tons of chlorine gas from a 
lineup of 5700 canisters. Carried by the wind, the gas passed in minutes to the French and British trenches and quickly killed 1000 soldiers and injured another 4000. This surprise attack provoked competition to discover more potent chemical weapons, with the Germans, British, Italians, Russians, and later the Americans engaging in an unprecedented arms race (Lepick 1998). Soon phosgene, mustard gas, and an assortment of tear gases and blistering agents (vesicants) were in battlefield use, causing death, burns, blindness, other injuries, and terror among surviving combatants. The race was also on to develop masks, suits, and blankets that could protect troops from gas attacks.

World War I brought a scale of devastation in terms of deaths and economic and political upheaval that outstripped all previous wars (MacMillan 2013). When it ended in 1918, international cooperation among nations, backed by law, appeared necessary to prevent future chaos. Supported by a range of visionaries, the creation of the League of Nations in 1920 heralded a new, institutional approach to peace centered on the political resolution of state conflicts before they escalated (Kennedy 1987). Members would, in theory, submit to arbitration rather than take up arms and they would act in each other's defense in the event of unprovoked aggression. The 1922 establishment of the Permanent Court of International Justice (PCIJ) at The Hague offered the option for member nations to settle their disputes through legal hearings, which they did, at a rate of five cases per year for the next decade (ICC 2012).

The League also promised a radically new era of arms control. By Article 8 of its Covenant, members affirmed that "the maintenance of peace requires the reduction of national armaments to the lowest point consistent with national safety and the enforcement by common action of international obligations" (Ames 1922, 306). Also in Article 8, member states agreed to "full and frank information as to the scale of their armaments, their military, naval and air programs and the condition of such of their industries as are adaptable to warlike purposes." Although the United States, reverting to an isolationist posture, refused to join the League, its representatives maintained an active presence in its deliberations and arms control initiatives. The new Soviet Union was distinctly an outsider, but its emissaries did attend important debates.

In addition to the League's active agenda, the international community began building on the 1907 Hague Conventions. In the spirit of arms control, Americans took the lead in assembling the 1922 Washington Conference on the Limitation of Armaments, which resulted in a treaty to restrict poison gas and submarine warfare (SIPRI 1971, 46-47). The United States, the United Kingdom, France, Italy, and Japan, recognized as the premier military power in the Far East, signed the treaty. Because of French objections to the provisions about submarines, the Washington Treaty of 1922 never came into force; yet it paved the way for the 1925 Geneva Protocol which forbade the use of chemical weapons in war. The text of the Protocol banned the use of "asphyxiating, poisonous or other gases, and of all analogous liquids, materials or devices" already "justly condemned by the general 
opinion of the civilized world" and "universally accepted as part of International Law, binding alike the conscience and the practice of nations" (SIPRI 1971, 341). To this provision, the treaty added that the prohibition would be extended to a looming innovation, "the use of bacteriological methods of warfare."

Despite its strong resolve, the Protocol raised an uncomfortable issue: what would be the international political repercussions if it were violated? In principle, the reaction of the League of Nations should have been two-fold: that the member states would act as restraints on each other and that, as a bloc, they would come to the aid of any member aggressed upon by another state. The implication of the treaty's text was that even states opting not to join would be beholden to established laws of war.

The Geneva Protocol was widely embraced in the interwar years; 43 nations became parties, with the British Empire, France, Italy, Germany, and the Soviet Union leading the way. From the outset, however, it was no guarantee against chemical or biological weapons proliferation. Instead, it allowed a provision for retaliation in kind, which meant that, based on the perception of an imminent or even a long-range threat, each state on its own could decide the level of research, development, and munitions production it needed for adequate defense.

Two important nations, the United States and Japan, refused to join the treaty. In an isolationist phase, the US Senate refused to ratify the Protocol, although sentiments against chemical warfare were strong in America and the US Army had little inclination to reenact the excesses of World War I (Brown 2006, 49-96). In principle, the United States adhered to the treaty's ban on use and limited itself to retaliation in kind. Its Chemical Warfare Service, invented late in World War I, languished and it had little inclination to investigate germ weapons (Guillemin 2005, 27).

Japan refused to become a party to the Geneva Protocol for different reasons. Having shown its military strength in its 1905 war with Russia, Japan was considered Asia's most advanced nation by Western powers, especially the British and Americans. With its population and industries growing and its natural resources limited, Japan had already annexed Korea, acquired Taiwan, and established a profitable lease for trade in Manchuria (Northeastern China). As Japan's ambitions to solidify its empire grew, so did its interest in modern, science-based weapons, including chemicals. During World War I, the Japanese military was more intrigued than repelled by Europe's chemical warfare and, following the war, its experts moved ahead to develop chemical agents with techniques learned in Germany and the United States. In 1928, Japan built a production facility on Okunoshima Island, near Hiroshima, mainly for mustard and tear gases. By that time, its Army Institute of Scientific Research included forty chemical weapons laboratories, twenty affiliated workshops, and an annex staffed with hundreds of scientists and technicians (Grunden 2005, 181-182). 


\section{World War II and the Post-war IMTFE}

Even as the League advocated peace, the concept of total war, with scenarios of air attacks on enemy civilians, cities, and industrial centers behind the lines, was taking hold among state powers (Buckley 1999). As early as 1921, the Italian General Giulio Douhet, a pioneer of strategic bombing, predicted that aeronautics would open up a revolutionary new way to make war. "Air power makes it possible," he wrote, "not only to make high explosive bombing raids over any sector of the enemy's territory, but also to ravage his whole country by chemical and bacteriological warfare" (Douhet 1942, 6-7).

In the early 1930s, the legal means to lasting peace began unraveling. One of the first aggressive actions came from Japan, where moderates and militarists struggled over how to achieve Japan's destiny as a great power (Jansen 2002, 576-585; Gordon 2014, 181-199). In 1931, feeling the impact of the great world depression —its foreign trade had been halved since 1929_-Japan made a move that violated the international "Open Door" policy for China that it had agreed to in 1922, in affirmation of China's right to sovereignty, territorial integrity, and control of its national destiny. Claiming Chinese troops had attacked the Japanese Kwantung Army at a railway junction near Mukden (Shenyang), Japanese troops soon conquered Manchuria. At a meeting in Geneva in February 1933, League members voted for Japan's withdrawal. Japan's reaction was to quit the League. That year, Nazi-controlled Germany also quit, claiming that the League's World Disarmament Conference had acted with prejudice by denying it arms parity with France.

Fascist Italy was the next to leave the League. Its 1934-1936 war with Ethiopia was patently aimed at increasing Italy's colonial holdings in Africa. The League attempted reconciliation between the two members, but to no avail. Starting in December 1935, Italy violated the Geneva Protocol by using asphyxiating and poisonous gases on undefended Ethiopian troops and civilians (SIPRI 1971, 175189). The response of League members was uneven and tepid, establishing a precedent of non-intervention. Despite protests from Ethiopia's Emperor Haile Selassie and documented proof of gas casualties from Red Cross physicians, the League failed to implement effective military and trade sanctions against Italy or deter further gas attacks. The conflict ended in May 1936 with Ethiopia's defeat and its incorporation into Italian East Africa. Italy exited the League soon after.

In July 1937, the Japanese used a conflict on a rail line near Beijing as an excuse to instigate war against China to expand their territory. After quickly gaining control of Beijing, the Japanese captured Shanghai and then China's capital Nanjing. League members protested, but none rushed to openly confront Japan in China's defense. In October of that year, China's delegates to the League protested Japan's use of chemical weapons (identified as mustard gas) on defenseless Chinese troops on the path from Shanghai to Nanjing (SIPRI 1971, 189-192). In 1938, the Chinese returned with documented accusations of more Japanese chemical attacks. But as in the case of Italy's attacks on Ethiopia, League 
members did not rise to China's defense; it could only remind its members that "the civilized world" had rejected chemical weapons.

On September 1, 1939, Germany invaded Poland and another catastrophic world war began. By then, Germany, Italy, and Japan had found common ground in their alliance as Axis powers, which was sealed by the 1940 Tripartite Pact. Japan's surprise attack on Pearl Harbor in December 1941 brought the United States into the war and extended the Allied-Axis conflict to the Pacific and Asia. In 1942, the Chinese reported to the Allies that Japan had attacked four of its cities with plague, killing hundreds; in the tumult of the war, BW experts in the United Kingdom and the United States dismissed this complaint as not credible (Guillemin 2017, 15).

In a short time, World War II demonstrated that, armed with advanced weapons, especially long-range bombers, major industrial nations at war could wreck the globe (Buruma 2013). From 1939 to 1945, some 60 million people were killed, once-thriving cities and natural environments were laid waste, major states went bankrupt or nearly so, masses of people were forced to migrate and died of epidemics, exposure, or starvation, and political instability became a norm. In Germany, Poland, and the Soviet Union, entire populations were murdered in Nazi concentration camps and in mass executions on the eastern front. Allied troops died by the hundreds of thousands on the western front, German and Soviet soldiers died by the millions in the East. In the Pacific-Asia region, the estimated body counts, difficult to reckon in poor and disadvantaged countries, matched those in Europe.

At the war's end, the Allied response was to create the United Nations as a fortified reincarnation of the League of Nations - this time with a provision for armed peace-keeping intervention and a new court for conflict resolution. A complementary Allied response was to invent the international military tribunal (IMT), staging one in Nuremberg, Germany, and the other in Tokyo, to prosecute the high Axis leaders individually for their war crimes. Three major criminal charges were agreed on: first, for the waging of aggressive war (including conspiracy in its promotion and planning); second, for the violation of the customary rules of war; and, third, for crimes against humanity, pertaining especially to the torture and killing of civilians (Taylor 1992, 56-74).

Compared to the spirit of the immediate post-World War I years, the fervor for arms control in 1945 was singularly lacking. To the contrary, advanced weaponry was competitively sought. The Allies in Europe (the Americans, British, Soviets, and the French) sought to appropriate as much as they could of Nazi Germany's arsenals, from V-2 rockets to nerve gases (Jacobsen 2014). In recruiting expert German physicists, chemists, and biologists, the unsavory and even criminal aspects of their careers were suppressed. Similarly, in Japan, the US Army and its G-2 intelligence division in Tokyo diligently sought to ascertain what, if any advances in weaponry could be acquired as "war booty" (Home and Low 1993). The mobilization of American industry and science for military goals had succeeded in winning the war; the result was a validation of strategic weapons, from incendiaries to conventional bomb, culminating in the atom bomb which immediately became "a symbol of industrial might, scientific accomplishment, and national prestige" (Cirincione 2007, 17). 
In principle, the second category of IMT war crimes, concerning customary rules of war, included violations of the Hague Conventions and the 1925 Geneva Protocol, along with treaties on the treatment of POWs and non-combatants. Encouraged, China decided to revive its wartime chemical and biological warfare charges against Imperial Japan. The Japanese had signed the Hague Conventions and, although not a party to the Geneva Protocol, the ban on chemical and bacteriological weapons use in war was internationally accepted. With that intent, along with charges of unprovoked war and mass killings, Chinese prosecutors arrived early at the International Military Tribunal of the Far East (IMTFE), which began organizing in December 1945 and opened in May 1946.

Using basically the same charter as the Nuremberg International Military Tribunal (1945-1946), the IMTFE put 28 defendants on trial, including former Ministers of War and those who had been high-ranking field commanders in Manchuria and China. Since Nazi Germany had refrained from using its chemical weapons during the war and had not developed biological weapons, the Protocol was fairly irrelevant at Nuremberg. The Chinese calculated that the Tokyo trial was the right forum to settle its old CBW scores.

\section{Retrieving CBW Evidence from China, 1946}

Eleven nations were represented at the IMTFE: the United States, the United Kingdom, the Soviet Union, France, China, Australia, New Zealand, the Netherlands, India, and the Philippines. Each was entitled to send an Associate Prosecutor to head its division at the International Prosecution Section (IPS), the IMTFE's cooperative organization for selecting defendants, composing the Indictment, and arguing the Allied cases. The IPS was also in charge of organizing war crimes evidence against those accused. The Chinese Section had virtually no staff, just its lead prosecutor, Hsiang Che-chun (Xiang Zhejun), and his assistant, Henry Chiu. In an unusual gesture of support, Joseph B. Keenan, the IPS Chief of Counsel, sent an investigative team to China on a month-long investigation to track evidence and identify witnesses who could testify at the trial on behalf of the Chinese Division (Keenan 1946).

On March 12, 1946, two American IPS lawyers, Colonel Thomas Morrow and civilian David Nelson Sutton, along with Henry Chiu, began their investigation, which took them to Shanghai, Beijing, Chongqing, and Nanjing (Guillemin 2017, 105-157).

Sutton was responsible for investigating the BW allegations, which proved difficult. He interviewed knowledgeable public health physicians who had reported on the plague outbreaks, but none had actually seen the Japanese air attacks, which had targeted small war-torn cities in Central and South China. No testimony at the time had been taken from victims and Sutton had no mandate to conduct an 
intensive field inquiry. General Ishii Shiro, the leader of the Japanese germ weapons program, centered at Unit 731 in Manchuria, had cleverly intended to mask the plague attacks so that they would seem to be naturally caused - and he had largely succeeded. Sutton was able to gather substantial evidence for Japan's 1937 conquest of Nanjing and the ensuing seven weeks of massacres, rapes, and looting, and for the Japanese opium enterprise, which had enslaved many Chinese communities, but not for the plague attacks.

After returning to Tokyo, Sutton submitted his report on allegations of Japanese bacteriological warfare to Chief of Counsel Keenan. He also sent a copy to General Douglas MacArthur, Supreme Commander for the Allied Powers (SCAP) and head of the Allied Occupation, the ultimate authority in Tokyo, even though he professed to keep a distance from the IMTFE. Sutton's conclusion was succinct: "As the case now stands, in my opinion the evidence is not sufficient to justify the charge of bacteria warfare" (Sutton 1946, 1).

Morrow and Sutton were both aware that a CWS officer was in the process of interviewing General Ishii and a dozen of his former Unit 731 staff; the news had been leaked to the military newspaper Stars and Stripes the previous February (Kalisher 1946). That inquiry, Morrow had been advised, was for CWS and G-2 "war booty" purposes alone. Although Sutton later made other inquiries about Japan's BW program, IPS was left with his original assessment: the evidence for Japanese BW, which killed hundreds and terrorized thousands, was insufficient for prosecution. Another question troubling the Chinese charge concerned the problem of linking any such attacks to particular defendants in the dock. How could germ weapons be developed and used without the knowledge of the high command in Tokyo?

In contrast to Sutton's BW inquiry, Colonel Morrow's March-April 1946 investigation of Japanese chemical weapons use in China yielded documents and eye-witness accounts highly suitable for trial. On returning to Tokyo, Morrow wrote up a detailed summary of what he had acquired and, on May 13, he and Kenneth N. Parkinson, another IPS attorney, included it in their "Form of Brief" on "All China Military Aggression, 1937-1945," which they submitted to Chief of Counsel Keenan and to General MacArthur (Parkinson and Morrow 1946a). Following a detailed IPS outline, the draft described each of the relevant counts of the Indictment as they related to China's charges against Japan and it listed the names of witnesses ready to testify. The summary covered the Sino-Japanese War from July 7, 1937 until Japan's surrender in September 1945.

Colonel Morrow's special contribution to the draft was his evidence for Japanese CW against China, which he included with Japan's other war crimes:

This waging of war by Japan in China was characterized by gross violations of international law and treaties, by massacre of civilians and Chinese soldiers, prisoners of war, and by the outlawed use of poison gas (Parkinson and Morrow 1946a, 7-8).

Starting with potential trial witnesses, Morrow drew on an affidavit from a Major General Chang, deputy director of China's Army Medical Corps, who stated that the Japanese used poison gas at Ichang (outside Shanghai), where Chang 
"personally saw men who were burned about the eyes, arm pits, and the crotch whose cases were diagnosed by himself. He saw 30 or 40 soldiers affected this way." (Parkinson and Morrow 1946a, 8). A photographer at the scene, a gas defense officer of the 34th Army group, could testify to having observed the soldiers burnt by vesicant gas. In addition, Brigadier General Wang Chang Ling, director of the gas defensive administration, could testify that in 1943 he found on the battlefield fifteen-centimeter howitzer shells containing hydrocyanic acid and that he saw a dozen soldiers suffering from gas poisoning by the Japanese, three of whom died. The general still had his notebook describing the analyses of contents of the shells. Finally, the director of a museum of chemical munitions near Chongqing was willing to describe the spent Japanese vesicant bombs and shells that he and others had brought back from battlefields.

As for official data, Major Woo Chia Shing of the Chinese Army, a custodian of records obtained from the Japan's Ministry of War in Tokyo, stated that 26,968 persons were injured by poison gas in the Sino-Japanese War, of whom 2086 died. These records, he said, verified that gas was used by the Japanese 1312 times in ten battles (Parkinson and Morrow 1946a, 8). Morrow then referred to Japan's secret chemical plant at Okunoshima.

Weapons from there, including mustard and lewisite, were shipped to China; Documents and testimony from Japanese officers connected with chemical warfare indicated that gas warfare was used in emergencies with the permission of Tokyo up to and including 1942 (Parkinson and Morrow 1946a, 8).

Meanwhile, the US Chemical Warfare Service (CWS) had an interest in not having Japanese chemical weapons use prosecuted as a war crime; that notoriety could only limit its own agenda to develop offensive weapons. While Morrow was still in China, Lieutenant Colonel John Beebe from the CWS office in Tokyo began conducting his own inquiry - which was part of larger G-2 project to assess Japan's chemical weapons. First Beebe interviewed former Premier Tojo Hideki and former War Minister Hata Shunroko, then being held at Sugamo Prison, and then, in addition, four other Japanese officers who might know about Japan's chemical arsenal and use.

In response to Beebe's questioning, Tojo insisted that although chemical stocks had been produced, none had been used and could not have been used without his permission. He had heard President Roosevelt's 1942 warning about retaliation in kind:

I thought, as I had from the beginning, that the use of gas would be disadvantageous for Japan because of tremendous America's industrial capacity and this statement of the President strengthened my own ideas (Interrogation of Tojo 1946, 4).

Tojo admitted that the Japanese did use "harassing agents" such as sneezing agents, tear gas, and smoke (as opposed to "casualty agents"). When asked if these non-lethal weapons were banned by international treaties, he replied defensively that police forces all over the world used them with impunity, including those in the United States who wanted to quell riots. "And what about the atom bomb?" he 
added. Changing the subject, Beebe confronted him with Japanese field reports that Chinese soldiers had died of asphyxiation from gas attacks, with blood running out of their noses and mouths. Tojo attributed these deaths to the Chinese overreactions to harassing agents and to their sometimes fatal inexperience with using gas masks.

General Hata had been in command of the Central China Expeditionary Force in 1938 and in 1941-1944 he was the Commander-in Chief of all the China armies. He denied any Japanese use of chemical weapons, allowing only that sneezing and tear gas might have been used (Interrogation of Hata 1946), nor had he ever heard of China's complaint to the League of Nations. The four other officers Beebe interviewed similarly denied that any chemical warfare had been waged against the Chinese. One, a former commander at the Narachino Chemical Warfare School, admitted to the production of some munitions but insisted that the high command had forbidden chemical attacks. "If gas were used in China," he said, "it was just on the spur of the moment and not on the orders of high authorities" (Interrogation of Yokoyama 1946, 5).

If presented in court, would Colonel Morrow's CW evidence be enough to counter these denials? The opportunity never arose, due to the influence of CWS working with US military intelligence in Tokyo. In mid-May, Morrow was advised of the content of Beebe's interrogation and the argument for "the outlawed use of poison gas" was erased from the "All China Military Aggression" report. In its final version, dated May 24, Japan's use of "poison gas" was briefly mentioned in passing on its first page, and the Tokyo document citing Chinese chemical casualties of 26,968, including 2086 who died, was repeated from the earlier version, along with the admission that Japan was known to have manufactured "various types of poisonous gases." But all the trial-worthy evidence-the eyewitness testimony, diaries, photographs, and medical records of victims, the retrieved battlefield munitions - was excised (Parkinson and Morrow 1946b).

In addition, reasons were inserted, taken straight from Lieutenant Colonel Beebe's interviews of Tojo and Hata, why allegations against Japan should not be "over-emphasized." As the authors explained:

1) It does appear that gas was used only in emergencies and for the most part tear, sneezing, and vomiting gas was used and not the vesicants, 2) the amount of casualties inflicted on the Chinese as evidenced from their statistics was a very small proportion of the total casualties suffered by the Chinese during the war, which is well over 3,800,000 according to their own records, and 3) in their interrogations Generals Hata and Togo refer to the fact that in the United States we have used poisonous gases such as sneezing, vomiting and tear gasses in labor disputes and General Togo in his interrogation about gas, raises the question, 'How about the atomic bomb?' which he claims is a much more outrageous weapon of warfare than poisonous gas (Parkinson and Morrow 1946b, 31-32).

The intimation of this last point was that if chemical warfare charges were made against Japan, the defense would have leeway to introduce the Hiroshima and Nagasaki bombings as a way of undermining the legitimacy of American prosecutors. 
The revised report then dismissed China's first report to the League, and with it any reference to existing treaties:

The reference to the use of poison gas in this warfare appears to have been made in the form of a complaint by the Chinese to the effect that the Japanese army used gas in Shanghai three and four October 1937, but which the Japanese emphatically deny. We do not intend to offer this in evidence but merely invite the committee's attention (Parkinson and Morrow 1946b, 32).

From then on, as IPS was informed, all future evidence about Japan's alleged chemical weapons use would be distributed to staff by the head of the CWS office in Tokyo, Colonel Geoffrey Marshall.

With its criminal charges of chemical warfare reduced to complaints and its germ weapons charges without solid proof, the Chinese Division, heavily reliant on American support, focused on the prosecution of the more flagrant Japanese crimes resulting from "aggressive war" and on their "total casualties." These charges were successfully argued, with convictions of top Japanese leaders from the time of the conquest of Manchuria to the 1937 instigation of the Sino-Japanese War and through to August 1945 and Japan's surrender to the Allies. In November 1948, seven defendants, including Tojo, were sentenced to death by hanging, while the rest were given jail sentences ranging from life to seven years, with the exception of two of the accused who died during the trial and another who spent the trial in a mental institution (Brackman 1987, 454-462).

\section{Conclusion}

Over the years, the IMTFE has been criticized as an example of hypocritical "victor's justice" for its prosecution of war crimes - like the killing of civilians or abuses of POWs - of which the Allies and particularly the United States were themselves guilty (Totani 2008, 218-245).

The obstacles to justice that G-2 and the Chemical Warfare Service posed at IPS were too covert to attract public notice. By the summer of 1946, General Willoughby controlled all witness interrogations at IPS - in the name of national security — and he later engaged leading lawyers at IPS and General MacArthur in his project to protect General Ishii and some two dozen of his scientists from war crimes prosecution for inhumane medical experimentation and their role in multiple mass germ attacks on Central China in 1942 (Guillemin 2017, 244-284).

In the 70 years since the IMTFE, the history of chemical and biological weapons proceeded from state-level proliferation on an extravagant scale, at immeasurable cost, to eventual international restraints. The proliferation began with the United States and its Western allies and with the Soviet Union, which legitimized the Cold War excesses. In combination with nuclear arms, chemical and biological weapons became integral to the "weapons of mass destruction" model for small and developing nations in troubled regions of the world. The legal restraints began with 
President Richard Nixon's unexpected 1969 renunciation of offensive biological weapons on behalf of the United States and the 1972 Biological Weapons Convention and, after the end of the Cold War, the culmination of the 1993 Chemical Weapons Convention and its organized destruction of state CW munitions - a process that both increases political stability and public safety.

In retrospect, chemical weapons were early on recognized as deplorable and, had the world known of Japan's germ attacks on the Chinese, those weapons, too, would have been reviled and perhaps criminalized at the IMTFE. On a purely practical level, major states were late in understanding that, compared to conventional arsenals, chemical and biological weapons were cumbersome, liable to endanger friendly troops and civilians, and inefficient, given their unpredictable impact on targets. Nor had chemical and biological arms the annihilating power of atomic bombs, no matter how much their advocates over the years were able to persuade those who controlled state military budgets that strategic capability was always one step away.

A post-facto evaluation of chemical weapons as archaic is cold comfort for those populations who suffered from the post-war proliferation. These victims, as might have been predicted, were always defenseless populations. Egypt's attacks on Yemen in the 1960s and, worse, Saddam Hussein's use of poison gas during the 1980s Iran-Iraq War reached a crescendo with his nerve gas attacks on Kurdish villages.

The latest spill-over from the long years of proliferation is the 2013 sarin attacks on Syrian civilians in Ghouta, outside Damascus, a war crime for which proof of accountability has been lost, for the time being, in the fog of war, along with the 2017 sarin attacks in Kahn Sheykun in northern Syria. As with the Chinese in 1945, one hopes for justice in the name of victims of chemical or biological attacks. But what might that forum be? In 1949, Harvey Northcroft, the New Zealand judge at the IMTFE, wrote passionately of the need for a disinterested international war crimes court:

No nation or nations which established their own tribunals, when such a Permanent Court existed, could escape the imputation that their action was dictated by the desire for vengeance, or by other improper motives. A Permanent Criminal Court would, therefore, provide the greatest possible measure of insurance against the unscrupulous use of power by victorious nations in the future (Northcroft 1982, 136-137).

More than fifty years later, in 2003, the International Criminal Court (ICC), a United Nations initiative, opened as an independent resource for victims and states with no other avenues to justice. While the ICC represents a step forward in international criminal law, its few cases have been selected with care (prosecution on behalf of child soldiers in the Congo wars was its first), adjudicated slowly, and have addressed mostly sub-Saharan African conflicts. Echoing the Geneva Protocol, Article 8 of its statute refers to criminal sanctions against "employing poison or poisoned weapons" or "prohibited gases, liquids, materials or devices" such that any would cause "serious damage to health in the ordinary course of events, through its asphyxiating or toxic properties" (Schabas 2001, 305). 
The statute is clear, yet the court's mission focuses on international armed conflict rather than civil wars or internal conflicts. It is questionable whether weapons-specific atrocities would by themselves make a compelling case, even when civilians were murdered. In addition, in its brief history, the ICC has had to navigate between pressures from the United Nations Security Council and the uncertain cooperation of states in conflict zones, while also being burdened by the complexities of its own organizational evolution (Minow et al. 2015). The future will see whether those responsible for the sarin attacks on Ghouta will someday sit accused in the dock at the ICC or another court and whether the charges are framed as war crimes or, in broader acknowledgement of the harm done to civilians, as crimes against humanity.

\section{References}

Ames, C.B. 1922. Article Eight of the League of Nations. The Southwestern Political Science Quarterly 2: 302-310.

Boserup, Anders. 1973. The problem of chemical and biological warfare: CBW and the Law of War, vol III. New York: Humanities Press.

Brackman, Arnold C. 1987. The other Nuremberg: The untold story of the Tokyo war crimes trials. New York: William Morrow.

Brown, Frederic J. 2006. Chemical warfare: A study in restraints. New Brunswick: Transaction Books.

Buckley, John. 1999. Air power in the age of total war. Bloomington: Indiana University Press.

Buruma, Ian. 2013. Year zero: A history of 1945. New York: Penguin Press.

Cirincione, Joseph. 2007. Bomb scare: The history and future of nuclear weapons. New York: Columbia University Press.

Douhet, Giulio. 1942. Command of the air. Trans. Dino Ferrari. London: Faber \& Faber.

Gordon, Andrew. 2014. A modern history of Japan: From Tokugawa to the present. New York: Oxford University Press.

Grunden, Walter E. 2005. Secret weapons and World War II: Japan in the shadow of Big Science. Lawrence: University Press of Kansas.

Guillemin, Jeanne. 2005. Biological weapons: From state-sponsored programs to contemporary bioterrorism. New York: Columbia University Press.

Guillemin, Jeanne. 2017. Hidden Atrocities: Japanese germ warfare and American obstruction of justice at the Tokyo trial. New York: Columbia University Press.

Home, R.W., and Morris F. Low. 1993. Post-war scientific intelligence missions to Japan. ISIS 84: 527-537.

Hudson, Manley O. 1931. Present status of the Hague Conventions of 1899 and 1907. American Journal of International Law 25: 114-117.

International Criminal Court (ICC). 2012. History of the PCIJ. http://www.icj-cij.org/en/history. Accessed 10 Mar 2016.

Interrogation of General Shunroku Hata. 1946. US National Archives, Japanese War Crimes (JWC), RG496, Entry UD UP53, Box 342, Folder C-306, April 11.

Interrogation of Hideki Tojo. 1946. US National Archives, JWC, RG496, Entry UD UP53, Box 342, Folder C-306, April 2.

Interrogation of Takeshige Yokoyama. 1946. US National Archives, JWC, RG496, Entry UD UP53, Box 342, Folder C-305, April 17. 
Jacobsen, Annie. 2014. Operation Paperclip: The secret intelligence program that brought Nazi scientists to America. New York: Little, Brown.

Jansen, Marius B. 2002. The making of modern Japan. Cambridge: Harvard University Press.

Kalisher, Peter. 1946. SCAP locates and questions Gen. Ishii. Pacific stars and stripes, February 27.

Keenan, Joseph B. 1946. Directions to Sutton from Keenan. Tokyo war crimes trial collection, University of Virginia Law School, Section 1, Folder 1, MSSI Su 863a, March 3.

Kennedy, David. 1987. The move to institutions. Cardozo Law Review 8: 841-988.

Lepick, Olivier. 1998. La Grande Guerre chimique. Paris: Presses Universitaires de France.

MacMillan, Margaret. 2013. The War That Ended Peace: The Road to 1914. New York: Random House.

Minow, Martha, True-Frost, C. Cora, and Whiting, Alex, eds. 2015. The First Global Prosecutor: Promises and Constraints. Ann Arbor: University of Michigan Press.

Northcroft, Harvey. 1982. The Former New Zealand Member, International Military Tribunal for the Far East, to the Prime Minister, 17 March 1949. In Documents on New Zealand external relations: The surrender and occupation of Japan, vol. 2, ed. Robin Kay, 1736-1737. Wellington, New Zealand: P.D. Hasselberg.

Parkinson, Kenneth N., and Colonel Thomas H. Morrow. 1946a. Trial Brief All China Military Aggression, 1937-1945. Tokyo War Crimes Trial Collection, University of Virginia Law School, Box 2, Folder 2, MSS 93-4, May 13.

Parkinson, Kenneth N. and Colonel Thomas H. Morrow. 1946b. Trial Brief All China Military Aggression, 1937-1945. Tokyo War Crimes Trial Collection, University of Virginia Law Library, Box 3, Folder 4. MSS93-4, May 24.

Sartori, Mario. 1943. The war gases. New York: D. Van Nostrand.

Schabas, William A. 2001. An introduction to the International Criminal Court. Cambridge: Cambridge University Press.

SIPRI (Stockholm International Peace Research Institute). 1971. The Problem of Chemical and Biological Warfare: CB Disarmament Negotiations, 1920-1970, vol. 4. New York: Humanities Press.

Smart, Jeffrey K. 2004. History notes: Chemical and biological research and development during the civil war. CBIAC Newsletter 5: 3-11.

Sutton, David Nelson. 1946. Subject: Bacteria warfare. David Nelson Sutton Collection, University of Richmond Law Library, Folder 13, April 25.

Taylor, Telford. 1992. The anatomy of the Nuremberg trials. New York: Knopf.

Totani, Yuma. 2008. The Tokyo war crimes trial: The pursuit of justice in the wake of World War II. Cambridge: Harvard University Asia Center.

Open Access This chapter is licensed under the terms of the Creative Commons Attribution-NonCommercial 2.5 International License (http://creativecommons.org/licenses/by-nc/ $2.5 /)$, which permits any noncommercial use, sharing, adaptation, distribution and reproduction in any medium or format, as long as you give appropriate credit to the original author(s) and the source, provide a link to the Creative Commons license and indicate if changes were made.

The images or other third party material in this chapter are included in the chapter's Creative Commons license, unless indicated otherwise in a credit line to the material. If material is not included in the chapter's Creative Commons license and your intended use is not permitted by statutory regulation or exceeds the permitted use, you will need to obtain permission directly from the copyright holder.

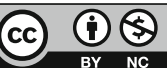

